\title{
The Schizomorphism of the world of visions in Bruno Schulz's prose
}

In this article I shall undertake to interpret Bruno Schulz's prose using the methodological proposals introduced in the discourse of humanities by Gilbert Durand, a French anthropologist of the imagination. Based on the implemented research perspective, the aim of the hermeneutics of The Street of Crocodiles and Sanatorium Under the Sign of the Hourglass will be to unveil and discuss the imagined figures which form the anthropological network of meanings. The methodological basis for the hermeneutics of the literary material will contain Durand's theory of the extra-cultural unity of imagination and the concept of a symbolic universe as an area of representation of anthropological imagination constructs ${ }^{1}$. The purpose of the array of anthropological and myth-criticism research tools used for analysing and interpreting the literary works, which constitute the core of Polish literature, is to define the author as an imagination phenomenon that seems to fill the research gap visible in Polish Schulz studies ${ }^{2}$. The process of the analysis and

\footnotetext{
${ }^{*}$ Marzena Karwowska, Ph.D., Chair of Polish Literature of the 20th and 21st Century, Institute of Polish Philology, University of Lodz, 171/173 Pomorska St., 90-236 Łódź, marzenakarwowska @poczta.onet.pl

${ }^{1}$ In Bruno Schulz's metalinguistic artistic manifesto entitled Mityzacja rzeczywistości (Mythicisation of Reality), the theoretical discussions revolved around notions which today are key for contemporary myth-critical and anthropological research and which describe man's symbolic universe: "Each fragment of reality lives because it shares some universal m e an in g. [...] Poetry constitutes short meaning connections between words, or sudden regenerations of primitive myths. When we use colloquial languages we forget that they constitute fragments of ancient and eternal stories, that we build, like barbarians once did, our homes out of broken pieces of sculptures and statues of gods. [...] The human spirit is tirelessly uttering life through myth, in giving sense to reality," B. Schulz, "Mityzacja rzeczywistości", [in:] B. Schulz, Opowiadania. Wybór esejów i listów, J. Jarzębski (ed.), Wrocław 1989, pp. 365-367.

${ }^{2}$ The nearly-100-year-old tradition of the study of Bruno Schulz's works, which began in the 1930 s, is burdened with a multitude of studies. In Polish literary science there exists an interesting phenomenon where the number of pages devoted to the interpretations of Schulz's works exceeds by several times the number of pages of his surviving output. His literary works (excluding essays) encompassing just two small prose series which included approx. thirty stories have remained the focus of several generations of literary scholars since 1933 when the Rój publishing house
} 
interpretation of the literary works will lead to a reconstruction of Bruno Schulz's imaginarium, to discovering the creative specific application of universal paradigms of imagery, to tracing the process of Schulz's re-updating of those paradigms, which is not just a simple reuse of mythical constructs inscribed in culture texts but a multi-faceted artistic device which applies to various levels of text organisation. Therefore, the aim of the research will be to trace the metamorphoses and the progression of mythemes, mythical figures and symbols on which the writer's imagination fed, and to offer the most comprehensive discussion of the anthropological imagination structures constituting the mundus imaginalis of the author of The Street of Crocodiles and Sanatorium Under the Sign of the Hourglass.

published The Street of Crocodiles. The most extensive companion of studies devoted to the works of Bruno Schulz, which is available at www.brunoschulz.org and includes approx. 100 pages, includes publications since 1922 (on Schulz's drawings). The first article discussing the literary texts by the author of The Street of Crocodiles was published in 1934 (T. Breza, "Sobowtór zwykłej rzeczywistości", Kurier Poranny, 1934, issue 103; section: "Na froncie literatury" (At the Literary Front)). Post-WWII literary scholars who commented upon the works of Schulz included: Jerzy Ficowski (Regiony wielkiej herezji. Szkice o życiu i twórczości Brunona Schulza, Krakow 1967; 4th edition, amended and extended entitled Regiony wielkiej herezji i okolice. Bruno Schulz i jego mitologia, Sejny 2002; Jerzy Speina (Bankructwo realności. Proza Brunona Schulza, Warsaw-Poznań 1974), Wojciech Wyskiel (Inna twarz Hioba: problematyka alienacyjna w dziele Brunona Schulza, Krakow 1980), Jerzy Jarzębski (Czasoprzestrzeń mitu i marzenia w prozie Brunona Schulza, [in:] Powieść jako autokreacja, Krakow 1984; Schulz, Wrocław 1999; Prowincja Centrum. Przypisy do Schulza, Krakow 2005); Krzysztof Stala (Na marginesach rzeczywistości. O Paradoksach przedstawiania w twórczości Brunona Schulza); Włodzimierz Bolecki (Język poetycki i proza: twórczość Brunona Schulza, [in:] Poetycki model prozy w dwudziestoleciu międzywojennym, Wrocław 1982); Władysław Panas (Księga blasku. Traktat o kabale w prozie Brunona Schulza, Lublin 1997); Tomasz Olchanowski (Jungowska interpretacja mitu ojca w prozie Brunona Schulza, Białystok 2001); Anna Czabanowska-Wróbel (, Powtórne dzieciństwo” w twórczości Brunona Schulza, Obraz Króla Olch w prozie Schulza, Fantazmaty dzieciństwa. Glosa do ,Wiosny” Schulza, [in:] Dziecko. Symbol i zagadnienie antropologiczne w literaturze Młodej Polski, Krakow 2003); Michał Paweł Markowski (Schulz. Za kulisami rzeczywistości, [in:] Polska literatura nowoczesna. Leśmian, Schulz, Witkacy, Krakow 2007). Many volumes were published as the result of domestic and international academic conference on Schulz (Studia o prozie Brunona Schulza, K. Czaplowa (ed.), Prace Naukowe Uniwersytetu Śląskiego w Katowicach, Katowice 1976; Bruno Schulz. In memoriam 1892-1992, M. Kitowska-Łysiak (ed.), Lublin 1992; Teatr pamięci Brunona Schulza, J. Ciechowicz, H. Kasjaniuk (eds.), Gdynia 1993; Czytanie Schulza. Materiały międzynarodowej sesji naukowej „Bruno Schulz - w stulecie urodzin i pięćdziesięciolecie śmierci”, Instytut Filologii Polskiej Uniwersytetu Jagiellońskiego, Kraków 8-10 czerwca 1992, J. Jarzębski (ed.), Krakow 1994; Bruno Schulz. 18921942. Katalog-pamiętnik wystawy ,Bruno Schulz. Ad memoriam w Muzeum Literatury im. A. Mickiewicza w Warszawie, W. Chmurzyński (ed.), Warsaw 1995; W ułamkach zwierciadła... Bruno Schulz w 110 rocznice urodzini 60 rocznice śmierci, M. Kitowska-Łysiak (ed.), Lublin 2003. In 2012 in celebration of the 120th anniversary of Bruno Schulz's birth and 70th anniversary of his death, the Chair of Philosophy of Culture, University of Warsaw, organised an interdisciplinary conference entitled Schulz. Między mitem a filozofia (Schulz. Between Myth and Philosophy). An extensive Schulz-focussed dictionary was developed (Stownik schulzowski, W. Bolecki, J. Jarzębski, S. Rosiek (eds.), Gdański 2006). 
I define, quoting Gilbert Durand, a symbol as a mythical figure (figure mythique) expressible at the language level of the archetypal image (image archétype) ${ }^{3}$. Imagination (mundus imaginalis) will be hereinafter considered as the Image-Bearing Awareness, a dynamic structure capable of introducing transformations, enabling decomposition and transformation of images ${ }^{4}$ in culture texts and their literary palingenesis.

The hermeneutic of Schulz's imagination proposed in this article focuses on the imagination chreod ${ }^{5}$, to which Gilbert Durand referred as a schizomorphic order of imaging ${ }^{6}$. A reservation must be made that the reality presented by Schulz was not an area of static constructs and antinomies; the presented analyses lead to revealing and highlighting the dynamic reorganisations of images.

The schizomorphic imagination chreod present in Schulz's prose should be considered as part of the cultural paradigm of the mythology of heaven ${ }^{7}$. It is

${ }^{3}$ Cf. G. Durand, Figures mythiques et visages de l'oeuvre. De la mythocritique à la mythanalyse, Berg International, Paris 1979, pp. 17-36. The diachronic approach and synchronic notion of symbol, cf. G. Durand, L'imagination symbolique, PUF, Paris 2003. Examples of understanding a symbol similar to that of Durand can be found in the following studies: F. Monneyron, "Le mythe et le mythique: bilan et perspective d'une hérmeneutique", Cahiers de l'Imaginaire, Paris 1992, pp. 123-138; L. Mattiussi, "Schème, type, archétype", [in:] Questions de mythocritique. Dictionnaire, D. Chauvin, A. Siganos, Ph. Walter (eds.), Imago, Paris 2005, pp. 307-317.

${ }^{4}$ Cf. G. Bachelard, La Poétique de l'espace, PUF, Paris 1957; La Poétique de la rêverie, PUF, Paris 1960. Regarding Bachelard's theory of symbols cf. G. Durand, "Scence objective et conscience symbolique dans l'oeuvre de Gaston Bachelard", Cahiers Internationaux de Symbolisme, 4/1963, p. 47; J. Libis, Bachelard et la mélancolie. L'Ombre de Schopenhauer dans la philosophie de Gaston Bachelard, Presses Universitaires du Septentrion, 2001.

${ }^{5}$ In his studies of culture texts, Gilbert Durand used a method which consisted in identifying, analysing and interpreting the figures of imagination (symbols, mythical figures, mythemes) of a given author which constituted the so-called semantic catchment areas to which he referred to as chreods. The goal of such a method was to create an imagination atlas of the author.

${ }^{6}$ Schizomorphic (heroic) constructs in the anthropological concepts by Durand formed antithetic images (light - darkness, top - bottom, knight - dragon, in West European culture best expressed in the topos of Drachenkampf) organised according to the principle of contradiction to which Gilbert Durand referred as diaïresis (Spaltung). Durand assigned the following archetypes to the schizomorphic constructs: verbal (divide $\neq$ combine, enter $\neq$ fall), epithetic (pure $\neq$ befouled, tall $\neq$ short), nominal (light $\neq$ darkness, air $\neq$ miasma, baptism $\neq$ taint). In the group of symbols and systems constituting the schizomorphic order of imaging, Durand placed a particular focus on the imagination figures firmly rooted in culture texts, such as: sword, sun, father, eagle, cf. G. Durand, Les structures anthropologiques de l'imaginaire, Dunod, Paris 1992.

${ }^{7}$ In referring to an essay by Schulz entitled Mityzacja rzeczywistości Włodzimierz Bolecki approached the issue of Schulz's formulated poetry and emphasised the significance of myths and symbols as the carriers of aesthetic concepts. The term poetic in Bruno Schulz's aesthetic concepts constituted "a transmitter of the primitive sense of the world - primitive myths", primitiveness (in Schulz's words: "mythicism") is a longing for the verbal original motherland, a state of "identity of sign and meaning, or such a situation when a sign and meaning are not yet isolated" (W. Bolecki, Język poetycki i proza: twórczość Brunona Schulza, [in:] Poetycki model prozy w dwudziestoleciu międzywojennym, Wrocław 1982, pp. 170-244). Stanisław Rosiek stressed the importance of myths 
formed by images and catamorphic figures. In Bruno Schulz's imagination one might identify the coexistence and intertwining of those two orders of imaging, both based on the principle of contradiction. Schulz often associated the images of rising and ascending in The Street of Crocodiles and Sanatorium Under the Sign of the Hourglass with his father; those were a series of strongly antithetic representations, all related to Jakub, already immobilised and trapped in his home by his illness. While the "physical I" experienced old age, illness, powerlessness, and a slump in vital strength represented by catamorphic figures (balls and chains of wall lamps, a crouching pose on a ladder, putting one's ear close to a gap in the floor), the "symbolic I" in Schulz's imagination balanced the situation (the Image -Bearing Awareness performed a symbolic "repairment") generating images oriented upwards (a ladder, the room's ceiling, curtain rails over high windows, stilts, birds, the sky, raised fingers). It seems interesting that the images associated with Jakub referenced above were void of any symbols of light, which often accompany images of ascending in culture texts. Light in Schulz's prose became, paradoxically, a catamorphic symbol vertically oriented downwards; such a semantic reversal was manifested in the visions of the balls and chains of wall lamps.

Gilbert Durand emphasised the constant, leading towards transcendence, isomorphism of the symbolism of lightness, ascension, and heavenliness ${ }^{8}$. Such a statement can be found in the works of Gaston Bachelard, who argued in his interpretations of the images of light that the same operations of the human mind direct us towards light and upwards": "When poetic intuition spreads throughout the universe, our intimate lives experience the highest levels of exaltation.

in the works of the author of The Street of Crocodiles arguing that the category constituted a central point in Schulz's world of ideas. He concluded, though, that all the analyses and interpretations of Schulz's output must be temporary in nature as we do not know the whole of his works and many texts constituting the corpus of his writings still await publication and reading (S. Rosiek, "Urzeczywistnianie mitu”, [in:] Czytanie Schulza. Materiaty międzynarodowej sesji naukowej „Bruno Schulz - w stulecie urodzin i pięćdziesięciolecie śmierci”, J. Jarzębski (ed.), Krakow 1994, pp. 164-177). When analysing the structure of time-space in Bruno Schulz's prose, Jerzy Jarzębski pointed out its symbolic potential and paradigmisation specific for mythical narratives. According to him, the mythical paradigm was used in The Street of Crocodiles and Sanatorium Under the Sign of the Hourglass as a model story aiding the individual in understanding their own existential situation or constructing a world-structure saving them from the premonition of death and the destruction of the world, J. Jarzębski, Powieść jako autokreacja, Krakow 1984, pp. 171; 180-181; J. Jarzębski, "Schulz i dramat tworzenia", [in:] W ułamkach zwierciadta... Bruno Schulz w 110 rocznice urodzin i 60 rocznice śmierci, M. Kitowska-Łysiak and W. Panas (eds.), Lublin 2003, p. 15). Sventlana Matvienko also identified the strategy of taming one's tanathic fears using symbolic-mythical modelling in Schulz's prose, thus inscribing his mythology in the extensive context of the philosophies of Georges Bataille, Michel Foucault or Jacques Derrida, cf. S. Matvienko, "Dyskurs autobiograficzny. Prywatna mitologia Brunona Schulza”, [in:] W ułamkach zwierciadta..., p. 191).

${ }^{8}$ G. Durand, Les structures anthropologiques de l'imaginaire, pp. 162-178.

${ }^{9}$ G. Bachelard, L'Air et les songes, Corti, Paris 1994, p. 55. 
Everything moves upwards, towards the clouds, light and the sky." ${ }^{10}$ In the story entitled Ptaki (Birds), the images of rising and ascending developed by Schulz were devoid of any glare because they were images of closure, while the space in which Jakub was placed was limited by walls and the corners of the room: the birds were the birds on the ceiling and the sky was the sky painted on arabesques; therefore, longing for transcendence could only express itself in the metaphysics of home which became an imagined home. Thus, in The Street of Crocodiles Schulz described a translocation of his father to two rooms in the attic, a birds' wedding organised by Jakub in the attic, while he presents his father's bird inn, the Noah's ark visited by "all kinds of winged creatures from faraway lands" [Ptaki, BS 24] ${ }^{11}$ as a space covered with a huge, gabled, shingle roof. The birds fed by Jakub in Schulz's imagination were "moving flowers fluttering in the air to finally spread around the upper regions of the room" [BS 23].

Images of illumination accompanying images of ascending appeared in The Street of Crocodiles many times in the story entitled Noc wielkiego sezonu (Night of the Great Season), where Jakub, contrasted with the blackness of the "flowing crowd" [BS 97] of buyers flooding the fabric shop during a sale, was presented as a glowing figure "with glaring eyes" [BS 98] amidst the silence of the shop, while the shop under siege was associated in the description with the aesthetics of glow: "Over the silence of the shop, there glowed a kerosene lamp, hanging from the huge ceiling, which ousted the smallest traces of shade from all nooks and crannies. The huge empty floor creaked in silence and counted in the light its glistening squares in all directions." [BS 97]. The image of ascending was associated at that point with the stylisation of the father as a prophet. Schulz used in a syncretic manner the symbols associated with the Biblical character of Moses ("at the strike of Moses' stick" [BS 99]; Sinai which "rose from the father's anger" [BS 100] and Jakub (the father wandering through the shop as if "among the folds and valleys of Canaan" [BS 99]). Through the imagined "autumning" [BS 102] landscape, which is a mental landscape, Józef's father, frozen at the highest shelves of the shop, could transcend its closed space. Schulz introduced there the images of opening ("extensive land", "catching fish in far off lakes", "a group of wanderers in the distance peering up to the sky" [BS 102] pointing up towards something with their hands). He enriched them by adding the isomorphism of the symbols of lightness, ascending, and heavenliness used in the description of the imagined birds [BS 103]. The opened extensive landscape was, however, a dying "autumning" landscape, thus becoming closed again, folding to the spiral form in the image of birds "circling around in large intersecting spirals" [BS 102]. The spiral was the oldest symbolic culture sign expressing in the cosmic plan the never-ending

\footnotetext{
${ }^{10}$ Ibid., p. 58 [trans. into Polish by M. K.].

${ }^{11}$ I quote all passages from Schulz's prose from: B. Schulz, Opowiadania. Wybór esejów i listów, J. Jarzębski (ed.), Wrocław 1989, pp. 365-367.
} 
transformation of that which is at the bottom immersed in darkness into that which is at the top and in light ${ }^{12}$. In Christianity, the cosmic symbol received a spiritual interpretation becoming a sign of a path to God through pain, a path symbolised by circular movement along a spiral instead of a vertical soaring towards the sky. An outward spiral, a journey away from the centre, expressed the evolution and growth of strength ${ }^{13}$. For those travelling along the spiral towards its centre (the starting point) the spiral meant the end and death. Schulz recalled the antithetic semantics of the image of a spiral as a figure of suffering in the character of his father. His interpretation of the symbol expressed the desire for a journey of the sick Jakub towards transcendence and freedom (amplified by the image of the birds), crossing the limitations of being closed and trapped, not only by the walls of the house and the shop, but also by his corporeality, illness, and feebleness. The journey on the spiral proved, in fact, a path to the end and death as the presentation of Jakub in The Street of Crocodiles leads the reader through a sequence of images of ascending to catamorphic images: from images of free birds circling in the sky, through the form of a spiral, an image of storks "flowing motionlessly with their wings spread wide", the image of crippled birds limping in the air, to the images of birds trapped forever in lifelessness resembling "poorly stuffed vultures and condors leaking sawdust" [ibid.], blind paper birds" - "hollow inside and lifeless" [BS 103]. The sequence culminated in an image of birds falling down: "Hit with a projectile, they hung heavily and withered mid-air. They were a formless pile of plumage before reaching the ground. [BS 103]. Gilbert Durand interpreted the dynamic images of falling present in culture texts as an epiphany of fear, a sign of man's tanathic fear, existential experience of time, and the symbol of time endured ${ }^{14}$. According to Bachelard, the fall, related to the speed of the movement, constituted for the Dreamer's Cogito a dynamic component of the awareness of time ${ }^{15}$, "electrifying time" ${ }^{16}$, as a terrifying aspect of Chronos. The entire fall, according to Durand, is a synonym of "pernicious and deadly time, morally presented in the form of a punishment." ${ }^{17}$ In Noc wielkiego sezonu, the catamorphic imaging combined with palingenesis of the myth of a fall can be found

${ }^{12}$ Joanna Ślósarska, who studied the cultural significance of the symbol of the spiral, wrote: "The evolution and involution symbolised with a spiral was associated in India with the notion of the karma journey. [...] The spiral fashioned in red copper is the African sign of creative word and speech as the strongest layer of activity in the world. Because of the presence of a spiral in natural forms, the shape is interpreted as a living sign inscribed in the book of the world given to man to be read and understood," J. Ślósarska, W świetle symboli, Łódź 1994, p. 49.

${ }^{13}$ J. Chevalier, A. Gheerbrant, Dictionnaire des symboles, Laffont/Jupiter, Paris 1976, vol. 4.

${ }^{14} \mathrm{G}$. Durand, Les structures anthropologiques de l'imaginaire, pp. 122-129.

${ }^{15}$ G. Bachelard, La terre et les rêveries de la volonté, Corti, Paris 1996, p. 350; 400.

${ }^{16}$ Ibid., p. 253.

${ }^{17}$ Potęga świata wyobrażeń, czyli archetypologia wedtug Gilberta Duranda, K. Falicka (ed.), Lublin 2002, pp. 60-61. 
in the description of the salesmen: "Where were the salesmen? Where were those handsome cherubs who were to defend the dark shop ramparts? Father suspected painfully that there they were, sinning in the depths of the house with man's daughters." [BS 97-98]. The story culminated in an extensive catamorphic image which expressed the defeat and the symbolic fall of the father: an image of a bird's carrion, once a great bird family now lying dead on the rocks, turned into "old carcass", "reeking repugnantly", without "any signs of a soul", resembling "hunched, bald, dead camels." [BS 104].

Images of ascending, associated with the figure of the father, appeared often in Schulz's prose. In Sanatorium Under the Sign of the Hourglass, Jakub deep in his illness remained "in a solitary service to the highest perfection" [Martwy sezon, BS 234], suffering from want for perfection surrendered to the "asceticism of the highest mastery." [ibid.]. Another example of such a structural device was the inclusion of Jakub in a series of images associated with the symbols of birds or rather, to use Bachelard's notions, with the poetics of flight and wings and inscribing the father in a vertical upward-oriented spatial layout. Jakub's translocation to the birds' dominion (two rooms in the attic where the father lived amongst the hum and gurgle of the birds) was a literary transformation of the cultural isomorphism of the images of ascending and spiritualisation: "Together with the flock my father, fluttering his arms, tried in terror to rise into the air. [...] A moment later my father descended the stairs of his dominion - a broken man, a banished king who had lost his throne and reign. [BS 25]. Once again Schulz balanced the images of ascending with catamorphic imaging (the symbolic act of descending the stairs) evoking a sense of defeat when facing that which is inevitable and which is much more powerful than any human spiritual efforts.

The poetics of wings constituted in Schulz's prose a factor which organised the chreod of the images of ascending associated with the figure of Józef. In The Street of Crocodiles, the images were represented with the symbols of flight, observable in the description of the character rambling around a labyrinth of night-time streets: "Encouraged by the desire to visit cinnamon shops, I turned to a street I knew and I rather flew than walked making sure I did not lose my way" [BS 62]. In a story entitled Wiosna (Spring), the figures of ascending, representing the power of the thought and the spirit, were associated with the characters of Józef and Jakub; the device of character spiritualisation (the aesthetics of a glare, the symbols of lightness) served the purpose of emphasising, so characteristic of Schulz, the Logos - Bios antithesis. Bios in Wiosna was a "human event" [BS 137], which for Schulz was a synonym of an "outflow of thought" [BS 136]. It was represented by: "mugs of bitter beer", "forks and knives clattering over tables covered with white tablecloths" [BS 136], "the shambles of disarrayed napkins" [BS 137], hemming musicians preparing for a performance while the semes (sour, shambles) used in the fragment referred to indicated the negative evaluation of the described phenomena. Further in the story, in a part which raised 
the problem of anamnesis and regression to subconsciousness, Schulz gathered images which evoked Bachelard's phenomenological interpretations of the symbols of an oniric home. "A return route to the roots" - "a journey to oneself" [BS 158] undertaken by the protagonist lost in a deep oniric introversion was saturated with bright images of ascending and nyctomorphic images of a fall, while the analysed visions were clearly transferred to the anthropological layer: "It is only high up, in the light - it must be clearly said - that we are a trembling articulated beam of melodies, a bright larking peak - deep down inside we fall apart back to a black murmur." [BS 158]. In Sanatorium Under the Sign of the Hourglass, Schulz described Józef's journey up the town. The spatial structure used in the story copied the vertical layout of the spatial structure where the upward motion was evaluated positively while the downward motion was evaluated negatively. The upper town was an area where the protagonist moved calmly, in quiet, observing a swarm of beetles dancing around a street lamp "carried by the motions of vibrating wings" [BS 272], the lower town was immersed in conflict, war, it was terrorised by a hostile army equipped with rifles, a crowd of intimidated inhabitants was paralysed by the "terror of tilted barrels" [BS 271], and the silence was split by the rumble of artillery.

A similar spatial structure could be found in Sanatorium Under the Sign of the Hourglass in the description of the space of Józef's family house, in a story entitled Edzio (Little Ed). Schulz presented the lower part of the building, which together with the adjacent courtyard was immersed in darkness, using the image of putrefaction: decay and decomposition were presented through descriptions of a rubbish dump and scavenger ants ${ }^{18}$. The upward motion (the motion of air rising from the bottom of the courtyard towards higher sections of the house) was described by Schulz with the use of vital images of fertility (the symbol of a $\operatorname{frog}^{19}$ ) and celestial images (the sky filled with starlight, [BS 289]). The celestial onirism represented by constellations - light filled with mildness and glare in Bachelard's phenomenology of imagination enabled the Dreamer to endure the hardships of worldly life, granting its cosmic powers to isolate him from that what

${ }^{18}$ Ants possess in their semantic field strong associations with tanathic symbols. They constitute an element of Slavic mythology as creatures related to the Netherworld, cf. K. Moszyński, Kultura ludowa Stowian, Warsaw 1967, vol. 2, p. 550. More on the symbolism of ants, cf. M. Karwowska, Prapamięć uśpiona. Świat wyobrażeń Bolesława Leśmiana, Warsaw 2008, pp. 143-146. In Leśmian's imagination, ants existed in a different symbolic function than in Bruno Schulz's imagination; for Leśmian's protagonist, they were companions in a descent to the chthonic void in search of immortality. In Leśmian's works, ants appeared alongside vital images of regeneration.

${ }^{19}$ In culture texts, the frog is a lunar and aquatic animal representing the symbolism of fertility associated with water as hylogeny, the potentiality of all life. The metamorphosis the frog undergoes in its life cycle makes it, as an imagination figure, a symbol of regeneration and revival of vital powers. In vedic poetry, the frog represents an incarnation of the earth fertilised with the first drops of spring rain, cf. J. Chevalier, A. Gheerbrant, Dictionnaire des symboles, vol. 2, pp. 387-389. 
was worldly and temporal. By generating astral images, the Dreamer participated in a communion with Heaven ${ }^{20}$.

In Noc wielkiego sezonu, the space of Jakub's fabric shop was divided into a profanic zone (the lower part, the domain of the salesmen, prosaic, which was represented by the images of descending - human diminishing expressed through the crouching pose of the traders) and a sacred zone (high, the father's domain represented by images of Jakub's anger as an image of ascending, amplified with Biblical symbolism, [BS 100]). Schulz employed the poetics of wings not only in the case of the characters of Jakub and Józef. It also existed in sections of his prose devoted to aesthetic problems and matters related to art, e.g. in a story entitled Ksiega (The Book) where the title pages of the book "rose above the zone of everyday issues within the region of pure poetry." [BS 112] Another important semantic circle constructed through the images of flight (white doves) are the fragments of text raising the existential problems of man as a being trapped in earthly banality, a being "hardened through prose and commonness." [BS 111] The oniric flight, which presented in Sanatorium Under the Sign of the Hourglass the dreams of ordinary people, imagined in the form of a white dove, the symbol of heavenly purity, soul and winged human endeavours, in Schulz's prose expressed the want of deliverance and ascension above the meagreness and stillness of grey everyday worries, symbolised by the faces of people with motionless teary eyes, broken, drained, unclear faces, "eaten out by life", "covered with cobwebs" [BS 112]. In a similar symbolic function operating in Genialna epoka (Ingenious Epoch) the image a pigeon inscribed in the poetics of wings, amplified by the image of an opened window and the symbol of glare where birds were contrasted with the visions of home as a prison - a dark room where Józef lived was a space "closed shut, walled off its meaning" [BS 131], the opened window in the room allowed the inflow of "waves of air in gentle pulses." [ibid.] The image of a telescope raised towards the sky could be read as a symbol of crossing the earthly limitations of being, in Sanatorium Under the Sign of the Hourglass it possessed its semantic homologue, i.e. the image of an astronomical refractor of "outstanding light power" [BS 261] - a refracting telescope reproducing the image by refracting rays of light, to which Schulz referred as "far-sighter's bellows" [BS 261] and associated with the symbolism of ascension by a vision of a fluttering butterfly. Schulz's butterfly-telescope was, however, a figure of powerlessness since the writer compared it to a paper butterfly that in consecutive sequences of images morphed into a paper roach crawling on the ground, whereas the sequence of the images of ascending once again culminated in catamorphic images (falling, represented by the metamorphosis of the butterfly into a roach, was accompanied by emptiness and darkness).

${ }^{20}$ Cf. G. Bachelard, L'Air et les songes, Corti, Paris 1994, pp. 202-211. 
By creating images of clouds, imagination, according to Bachelard, invites us to rise all the way to the zenith of the sky, to ascend into heavens, to experience absolute sublimation, a final journey to the end ${ }^{21}$. The image of clouds in combination with the images of ascending could be found in the vision of heavenly ascension of the sleeping doctor Gotard in Sanatorium Under the Sign of the Hourglass. Schulz associated the figure of doctor Gotard with morbid and tanathic symbolism (the significance of black beard), thus his heavenly ascension was an attempt at a symbolic taming of death. One might have the impression, though, that the narrator was not convinced about the futility of those efforts of imagination as at that moment he used the grotesque convention - the clouds in the discussed fragment formed clusters of air exhaled by Gotard while he was snoring [BS 269]. One could find the combination of tanathic and catamorphic symbolism in Sanatorium Under the Sign of the Hourglass in the description of spring. Schulz engaged in a game with the cultural traditions of the symbolism of the season as a revival of the vital powers of nature, and booming life joyfully oriented upwards. The image of spring was inscribed in the aesthetics category of sorrow and expressed using images of dry dead parts of trees falling down, the coming dusk, a deadly breath spreading around the city park, and celestial tears falling down [BS 155].

While the images of ascending in Schulz's prose usually accompanied men (the father, Józef, doctor Gotard) and appeared in the contexts of such matters as art, imagination, spiritualisation, sublimation of man's spiritual powers, the symbolic attempt at overcoming the limitations of carnality, the strive for overcoming sickness and death, or the boundless boredom paralysing the city, the catamorphic images were usually associated with women and home, the domain of their influence. However, it was not a woman that is the falling figure; she was rather a cause of the fall that men experienced. The father, presented in Manekiny (Mannequins) as a "master imaginator" [BS 26], in Traktat o manekinach (Treatise on Mannequins) referred to as the "inspired heresiarch" [BS 37], in Ptaki, ruler in the birds' dominion in the attic from where he "seldom came down to the living space" [BS 25], fell to his knees in front of Adela taking the pose of a subject while his face tousled with inspiration enclosed in a submissive expression [BS 37]. Catamorphic images (Jakub's lowered eyes, sinking in himself, lowering his head, falling to his knees) were a response to Adela's raising the edge of her dress, stylised to embody the past time. Such a reading of Adela's character was alluded to in the scene by a prop which she was assigned by Schulz's imagination: a watch on a bracelet. All that is carnal passes; Schulz presented the delusive power of carnality and the charms of worldliness in yet another manner, by using the cultural isomorphism of the images of a woman and a snake, which were represented by Adela's foot draped in black silk sliding from underneath the raised dress resembling the mouth of the reptile. Adela was elevated, throned, inscribed

${ }^{21}$ Ibid., p. 220. 
in the aesthetics of glare (glistening shoe), sitting motionlessly in front of Jakub who lowered his head before her - the gesture foreshadowed the final surrender and defeat of the father the Demiurge expressed through his symbolic fall to his knees and embarrassed blushing that replaced the images of illumination usually associated in Schulz's prose with the character of Jakub.

One could also find the image of the fall in the visions associated with Józef's mother and Jakub's wife. The fullest expression of such semantics of the fall can be found in the symbolic metamorphosis of the father, once a ruler of the winged dominion, viewing the world from the birds' perspective, into a roach crawling on the ground (Schulz used the images of a crayfish, a crab and a scorpion interchangeably) in the story entitled Ostatnia ucieczka ojca (Father's Final Escape) which concluded Sanatorium Under the Sign of the Hourglass. In the visions of a crayfish-father, Schulz continued to use the images of ascending, but those were already considerably reduced to "slightly raised claws and antennas" [BS 314] and the "abdomen slightly raised above the floor" [ibid.] Jakub's wife caught the crayfish-husband on the stairs when he made his last effort to rise above his new ontology. Those were expressed at the symbolic level by jumping from step to step or the final short run up, but without rising above the ground, vertically on the wall "using the entire array of legs" [BS 314]. The mother, who could not hold in her hands the animal she found, asked her son: "Should I let it go on the floor?" [ibid.], then put the crayfish on a plate and put it on the floor from where the father made yet another epistemological attempt, this time horizontally: "As if he was learning anew the apartment from that new, crayfish perspective while adopting items. [...] He seemed to be somewhat pondering on the items found on his way." [BS 314]. The father, in earlier parts of the story, winged and elevated vertically in various images of ascending, having changed his bird's perspective to that of a crab, attempted a new type of symbolic journey: instead of the previous transcending ascents one could observe his attempts to squeeze through the breaks in the house, between the doors and the floor, motionless, silent lying under the table or drinking water from a puddle in the kitchen, while his favourite place for relaxing became the dip between the wardrobes and the wall.

In Bruno Schulz's prose the plan of ascension and the catamorphic plan, according to Durand representing schizomorphic imagination, played a significant role. The plan of ascension in The Street of Crocodiles and Sanatorium Under the Sign of the Hourglass was represented by: monarchic symbolism, images of ascending and heavenly ascension, imagination figures of birds and the verticalisation of the world of imagination, all referred to by the author of Les structures anthropologiques de l'imaginaire as symbols of separation ${ }^{22}$. Those images separated in

${ }^{22}$ Durand included among the symbols which fulfil the plan of ascending, present in culture texts, also such images as: a ladder, a mountain, a baetylus, angels, an archer, an arrow, a bow, cf. G. Durand, Les structures anthropologiques de l'imaginaire, pp. 138-178. 
Schulz's prose the male and female worlds, the children's and adults' worlds, the sacred and the profane, art (areas of pure poetry) and the trite grind of human events hardened through everyday matters, loftiness and commonness, Logos and Bios. The symbolism of ascending in the anthropology of imagination is interpreted as recapturing (restoring) once lost power. Therefore, by no accident Schulz's Image-Bearing Awareness usually associated those imagination figures with the figure of the father broken by his illness, crowning him as king of the birds' dominion located in the attic, or stylising him as a prophet speaking from Sinai in anger to the trading mob. The monarchic symbolism in culture texts is associated with the highest celestial reign, mythical figures of the father-king and priest-king. Schulz referred to those cultural contexts but he did not quote them directly, instead he transposed them. Interestingly enough, Schulz transferred the hyperbolisation of the symbolic figure of the king (Durand used the term gigantism) representing the culture's monarchic male might, power, and strength onto the construct of female characters (the throned Adela, the mother looking down on Jakub shrunk to a crab). The man in Schulz's world of visions lost that power, was subjected as a character to the artistic device of shrinking - he was either puny and broken with his illness as the father or, like Józef, diminished as a child character. A special example of the diminishing of the importance of a man could be found in the grotesque vision of the heavenly ascension of Doctor Gotard on the waves of snoring. Thus, the figure of a man in Schulz's prose was subject to a fickle process of semantic reversal of the cultural meanings assigned to it. The father undertook attempts to regain his lost power but, after the scenes of symbolic crowning as king of the birds' state in the upper regions of the house, Schulz offered the reader scenes of the dethroning of Jakub ("the banished king who had lost his throne and reign" [BS 25]) in favour of the ruling femininity, pragmatism, and worldliness. Thus, there is a description of Jakub descending the stairs of his dominion, the area of his reign: "Betrayed by everyone [...] voluntarily banished, removed himself to an empty room at the end of the hall." [BS 26]. The symbolic image of dethroning, a "dethroned ideal" [BS 208], could also be observed in Wiosna, where the narrator, upon an unsuccessful attempt at mutiny against the Demiurge, uttered the telling words: "I intended to read out to you [...] the act of my abdication. I abdicate. I resign." [BS 208].

The vertical model of space represented by the images of ascending and falling, though not the only model in Schulz's prose ${ }^{23}$, constituted a highly significant element of the presented world, facilitating the understanding of the

${ }^{23}$ Schulz used in his prose various spatial models: including the horizontal (a crab's epistemological perspective), a model based on the juxtapositions of: centre - periphery, close space - open space or the model based on sinusoidal lines: labyrinths, arabesques, and spirals. The variations of bending lines in the structure of the presented world constituted an opposition to the limitations of the classical cultural forms of spatial modelling; they could be read as yet another voice in Schulz's dialogue with tradition and culture; this is discussed in more detail in, cf. M. Karwowska, 
anthropological aspects of The Street of Crocodiles and Sanatorium Under the Sign of the Hourglass. The vertical structuring of the world of visions is interpreted in myth research as a model of dynamic processes ${ }^{24}$ and is associated with the trichotomous model of the cosmos, where the organising principle is the division into heaven, the earth and the netherworld. The division of space is a result of a juxtaposition of the positively evaluated upper area and the negatively evaluated lower area. In mythical narratives, one will find images of the upper world as the lore of gods and chosen people who go there after death, a land of happiness; and the lower world, the netherworld, as a place of the suffering of the dead as well as the place where chthonic demons reside. In mythical stories, there developed, along with the development of culture, the mythology of heaven, which in time gained a paradigmatic nature ${ }^{25}$. In Schulz's prose, one can find the paradigms of the vertical cosmic model and, processed by the artist's imagination, the mythology of heaven. The images of ascending (larks, pigeons, a ladder, Mt. Sinai), celestial and astral symbolism (a telescope, stars, the glow of the sky, the ceiling of the house as an ersatz celestial space), illumination, and the aesthetics of glare were balanced in Schulz's imagination by catamorphic symbols (the father's falling to his knees before Adela, the metamorphosis of Jakub into a crawling roach hiding in the breaks in the floor). The catamorphic images in Durand's concept of anthropological constructs of imagination were interpreted as the epiphany of fear, while the plan of a fall associated with the symbolic faces of Chronos was a reminder of our human mortal earthly fate ${ }^{26}$. Schulz transported artistically the isomorphism, defined by Durand and preserved in mythical narratives, of catamorphic and nyctomorphic images. The visions of a fall in The Street of Crocodiles and Sanatorium Under the Sign of the Hourglass often related to the tanathic symbolism of darkness expressed expressis verbis using representations (the blackness of Doctor Gotard's beard, the blackness of Adela's stockings). The cultural representations of the devastating, destructive time assumed in Schulz's prose the form of images of heaviness (hung heavy lamps and chains), dynamic images of a fall and descending (Jakub kneeling before Adela, father descending the stairs between Jakub's birds' dominion and the profane zone of the house), vertigo and shattering on the floor (the symbolic motion of the falling of shot birds).

When conducting a comparative analysis of culture texts based on mythical narratives, Gilbert Durand noticed that they often included imagination strategies of euphemising tanathic fears, which took the form of the feminisation and

\footnotetext{
"Spacery sceptyka przez rumowiska kultury. Bruno Schulz - o przechodzeniu do potomności - niepatetycznie", Prace Polonistyczne, series LXVI, 2011, pp. 217-227.

${ }^{24}$ E. Mieletinski, Poetyka mitu, trans. J. Dancygier, Warsaw 1981, p. 266.

${ }^{25}$ Ibid., pp. 266-267.

${ }^{26}$ G. Durand, Les structures anthropologiques de l'imaginaire, pp. 122-134.
} 
sexualisation of a fall ${ }^{27}$. In The Street of Crocodiles and Sanatorium Under the Sign of the Hourglass, one could find a revival of those mythical strategies of feminisation of a fall in the construct of the character of Adela (the father lowering his head before the throned Adela) and Józef's mother (Jakub crawling as a crab at the feet of his wife). Schulz's prose included an interesting sexualisation of the catamorphic pattern, visible in the relationship, based both on fear and erotic fascination, between Jakub and the maid (Jakub surrendering before Adela's foot seductively emerging from underneath a raised dress, the sensuality of which is further amplified by the black stockings, though also evoking strong tanathic connotations).

The Image-Bearing Awareness juxtaposed the negatively evaluated visions of the destructive time with the symmetric symbolism of escaping time, vanquishing fate and death. According to Durand, the very symbolic presentation of time is an imagination invitation to start therapy through images and fight $\mathrm{Chronos}^{28}$. Thus, in the world of Schulz's visions, imagination attempted to juxtapose the catamorphic images of the destructive time with the symmetric symbolism of vanquishing fate and death in the form of images of ascending. The images of ascending fit Durand's anthropological concept in the pattern of heroic structures of imagination dominated by two strong cultural symbols of strength and power: the sceptre and the sword. A comparative analysis of culture texts enabled Durand to identify the synthemes and symbols which constitute the imagination backbone of the pattern of ascending. It consists of: verticalisation (symbols of heavenly ascension), cratophany (the holy mountain, baetylus), the symbolism of wings (images of birds, de-animalisation of birds through the symbolism of wings in the imagined images of angles; Sophia; the Holy Spirit), the symbols of the highest celestial rule (gigantism and the power assigned to the mythical figure of father-king, combined with the symbolism of the monarchic power of the throned father-king, bearing a sceptre and the symbols of strength of the warrior-king imagined by the sword) ${ }^{29}$. All those elements of the mythical pattern of ascending could be found in Bruno Schulz's prose, though they were often subjected to significant semantic transformations, sometimes even to a semantic reversal. In The Street of Crocodiles and Sanatorium Under the Sign of the Hourglass, there were, as previously discussed, numerous examples of verticalisation of space: the symbolism of a ladder, the holy Mt. Sinai, birds (larks, pigeons), winged spirituality and wisdom. At the same time, however, the character of the father featured many de-mythologisation artistic devices. Schulz deprived Jakub of any attributes of the power of the warrior-ruler, replacing the cultural symbolism of a sceptre and a sword with morbid symbolism and the images of weakness. The mythical gigantism and

${ }^{27}$ Ibid., p. 63.

${ }^{28}$ G. Durand, Berło i miecz, trans. A. Szeliga-Ossowska, [in:] Potęga świata wyobrażeń, czyli archetypologia wedlug Gilberta Duranda, p. 69.

${ }^{29} \mathrm{G}$. Durand, Les structures anthropologiques de l'imaginaire, pp. 135-215. 
the monarchic power of the father-king were assigned in the world of Schulz's imagination to a woman (Aniela, equipped with a brush like a sword, conducts a symbolic dethroning of the ruler of the bird empire, and the image of the throned Aniela). Durand began his sceptre and sword analyses with a quotation from Bhagavad Gita: "Be not effeminate, O son of Prithâ! it is not worthy of you. Cast off this base weakness of heart, and arise." ${ }^{30}$ In Schulz's prose the father-king-man fell to his knees before triumphant femininity, the ruler became the servant, and Jakub's attempts at regaining his lost power ended in humiliation - humiliation of the cultural idea of a man, humiliation of the mythical idea of a king, and humiliation of the archetypal idea of a father.

The desire to release the essence of the being through the process of exteriorisation undertaken by Schulz's imagination, the images of ascending leading to spiritualisation, and the ontological liberation of the characters or the mythology of heaven in The Street of Crocodiles and Sanatorium Under the Sign of the Hourglass were immediately balanced by the mental process of interiorisation, which was dominated by catamorphic images expressing the defeat of the intellectual and the spiritual effort of the characters: Jakub, Józef, and the town inhabitants, in a fight with the deadly, worldly destiny of man. All those characters returned in Schulz's prose to the symbolic place of their fall, into which the oniric home turned and which was figuratively represented by the bedroom, the family house, the town, or the sanatorium. The imagination pattern of ascending mainly associated with the character of the father, the flight of the birds, starting with images of rising, opening and expanding space, spreading their wings, emanating glare, usually ended in the catamorphic images of descending, subsiding, closing of space, folding wings, interrupted flight, crashing against the rocks, dimming of the glare, immersion in darkness, dethroning Jakub, crawling on the ground, and finally the eventual changing of the bird's epistemological perspective into a crab's perspective in the closing story of Sanatorium Under the Sign of the Hourglass.

In anthropological and myth-critical studies researchers utilise, following Gilbert Durand, the now canonic definition of a myth as a dynamic system of symbols (mythical figures), archetypes, images, and patterns which form narratives permanently incorporated in culture. Thanks to the literary palingenesis of mythical narratives, archaic myths are revived each time through the dynamic nature of the story while the universal myth becomes a personal and individual myth as the "oldest verbalisation of super-individual and collective aspects of experienced reality." ${ }^{31}$ Jean-Jacques Wunenburger introduced the notion of mythical-poietic

${ }^{30}$ Ibid., p. 69.

${ }^{31}$ A. Deremetz, "Petite histoire des définitions du mythe. Le mythe: un concept ou un nom?", [in:] Mythe et création, Pierre Cazier (ed.), Lille, Presses Universitaires de Lille, 1994, p. 22. The phenomenon of personalisation of universal myths in the anthropological writings of Gaston Bachelard was indicated by Jean-Claude Margolin, cf. J.-C. Margolin, Bachelard, Seuil 1974, pp. 98-99. 
imagination defined as a special type of imagination where myths activate story -telling imagination which generates (based on mythical stories) fictional stories. ${ }^{32}$ The French philosopher associated mythical-poietic activities of imagination with symbolic activities..$^{33}$ Simone Vierne ${ }^{34}$, based on her extensive myth-critical studies, concluded that in literary works which carry fundamental archetypal images one can find a common core of an essence-based nature, yet the duality of creative imagination is the reason why the images achieve different artistic fulfilment in the works of specific authors, in specific historical contexts, and literary genres. ${ }^{35}$

The anthropology of imagination as a method of literary study placed its research focus on the mundus imaginalis of the creator understood as the manifestation of the symbolic powers of imagination, while the artist was considered as an imagination phenomenon. The images generated by the imagination of a dreaming subject constitute a continuously resonating mediation element between the external world of Nature and the internal realm of Psyche. ${ }^{36}$ The world of the creator's imagination, though founded on universal symbols of culture, is never uniform. The imagination researcher follows the "imagination trajectory" of the $\operatorname{artist}^{37}$, traces the metamorphoses, variations, and the progression of mythemes, mythical figures and symbols on which the creator's imagination feeds. The anthropological and myth-critical hermeneutics of the world of Bruno Schulz's visions, the analysis of chreods and imagination patterns, the search for the relations and the principles organising the images lead to a conclusion that the mundus imaginalis of the author of The Street of Crocodiles and Sanatorium Under the Sign of the Hourglass possessed the features of imagination to which Gilbert Durand referred as schizomorphic imagination ${ }^{38}$. In the world of Schulz's visions, imagination attempted to juxtapose the catamorphic figures of the destructive time (images of closing of space, folding wings, interrupted flight, crushing on the rocks, Jakub's dethroning, crawling on the ground, changing the bird's perspective to a crab's perspective) with a symmetric symbolism of vanquishing fate and

${ }^{32}$ J. J. Wunenburger, "Principes d'une imagination mytho-poïetique", [in:] Mythe et création, Pierre Cazier (ed.), Lille, Presses Universitaires de Lille, 1994, p. 36. The term poietic was borrowed from Aristotle for whom it meant man's craftsmanship. In imagination studies, the term means the productivity of the imagination, its creative potential thanks to which new creations are possible.

${ }^{33}$ Ibid., p. 40.

${ }^{34}$ Simone Vierne, who for many years managed the Centre de Recherche sur l'Imaginaire established by Gilbert Durand in Grenoble, studied the imaginations of Jules Verne and George Sand.

${ }^{35}$ S. Vierne, Rite, roman, initiation, Grenoble, Persses Universitaires de Grenoble, 2000, p. 159.

${ }^{36}$ J. J. Wunenburger, La vie des images, Grenoble, Persses Universitaires de Grenoble, 2002, p. 10.

${ }^{37}$ Ibid., p. 11.

${ }^{38}$ A different, night-time (as per Gilbert Durand's typology) type of imagination could be found when analysing the anthropological and myth-critical world of the visions of Bolesław Leśmian; those images, generated by imagination, were organised through combination and perseveration, cf. M. Karwowska, Prapamięć uśpiona. Świat wyobrażeń Bolesława Leśmiana, Warsaw 2008. 
death in the form of images of ascending (the symbolism of birds, a ladder, the holy Mt. Sinai, winged spirituality and wisdom, opening and extending space, spreading wings).

The analysis of the symbolic-mythical code of Bruno Schulz's imagination, through which the modelling of the anthropological space as a space for man's symbolic activities is fulfilled, clearly revealed an artistically processed, yet inscribed in the schizomorphic pattern of imagination, cultural model of homo patiens. From the whole array of imaginary constructs available to imagination, Schulz usually selected morbid imaging and images of enclosure for describing torment (the family house and the oniric house as a prison; the town as a prison, being trapped in the grind of events). At the same time he balanced and vanquished the figures of being trapped in a locked world at the level of artistic imagination using the figures of rehabilitation, liberation, spiritualisation, and sublimation, fitting the vertical celestial-solar pattern, the poetics of wings and the aesthetics of the classical element of air. Therefore, Schulz's mundus imaginalis was also formed by this anthropological pattern's inherent images of transcending space-time, images of ascending, birds, the wind, images of light, transcending human ontological limitations, overcoming the meagreness of the body plagued incessantly by illnesses as well as the images of horizontal opening of space, escaping outside the limits of the house, the courtyard, and the town. Schulz's mundus imaginalis was organised by the principle of balancing the constructs of imagination. The symbolic modelling through imagined figures generated thanks to the Image-Bearing Awareness, closely related to the therapeutic role of images, enabled the subject to regain his state of internal balance, to which Gilbert Durand referred as "anthropological balance" 39 .

\section{Bibliography}

Bachelard Gaston, L'Air et les songes, Corti, Paris 1994.

Bachelard Gaston, La Terre et les rêveries de la volonté, Corti, Paris 1996.

Durand Gilbert, L'Imagination symbolique, PUF, Paris 2003.

Durand Gilbert, Figures mythiques et visages de l'oeuvre. De la mythocritique à la mythanalyse, Berg International, Paris 1979.

Durand Gilbert, Les Structures anthropologiques de l'imaginaire, Dunod, Paris 1992.

Karwowska Marzena, Prapamięć uśpiona. Świat wyobrażeń Bolesława Leśmiana, Wydawnictwo Wydziału Polonistyki Uniwersytetu Warszawskiego, Warsaw 2008.

Libis Jean, Bachelard et la mélancolie. L'Ombre de Schopenhauer dans la philosophie de Gaston Bachelard, Presses Universitaires du Septentrion, Paris 2001.

Margolin Jean-Claude, Bachelard, Seuil, Paris 1974.

Mieletinski Eleazar, Poetyka mitu, trans Józef Dancygier, PIW, Warsaw 1981.

Mythe et création, Pierre Cazier (ed.), Presses Universitaires de Lille, Lille 1994.

${ }^{39}$ G. Durand, L'Imagination symbolique, PUF, Paris 2003, p. 116. 
Potęga świata wyobrażeń, czyli archetypologia wedtug Gilberta Duranda, Krystyna Falicka (ed.), Wydawnictwo UMCS, Lublin 2002.

Questions de mythocritique. Dictionnaire, Danièle Chauvin, André Siganos, Philippe Walter (eds.), Imago, Paris 2005.

Schulz Bruno, Opowiadania. Wybór esejów i listów, J. Jarzębski (ed.), Wydawnictwo Zakład Narodowy im. Ossolińskich, Wrocław 1989.

Wunenburger Jean-Jacques, La vie des images, Persses Universitaires de Grenoble, Grenoble 2002. Vierne Simone, Mythe, roman, initiation, Persses Universitaires de Grenoble, Grenoble 2000.

\section{Information on the author}

Marzena Karwowska, Ph.D. in humanities, literary scientist, member of the Chair of Polish Literature of the 20th and 21st Centuries, University of Lodz, conducts research in myth-criticism and the anthropology of creative imagination, and has participated in academic internships in the area at universities in France (Paris IV Sorbonne, Centre de Recherche sur l'Imaginaire - University of Grenoble). Original books: Prapamięć uśpiona. Świat wyobrażeń Bolesława Leśmiana, Warsaw 2008; Symbole Apokalipsy. Studia z antropologii wyobraźni, Warsaw 2011; Antropologia wyobraźni twórczej w badaniach literackich. Świat wyobrażony Brunona Schulza, Łódź 2015. Editor-in-Chief of the Prace Polonistyczne academic journal.

\section{Schizomorphism of the world of imagination in Bruno Schulz's prose}

\section{(Summary)}

In the article, I undertake to interpret Bruno Schulz's prose using the methodological proposals introduced in the humanities by Gilbert Durand, a French anthropologist of imagination. Based on the implemented research perspective, the aim of the hermeneutics of The Street of Crocodiles and Sanatorium Under the Sign of the Hourglass was to unveil and discuss the imagined figures which form the anthropological network of meanings. The purpose of the array of anthropological and myth-criticism research tools used for analysing and interpreting the literary works which constitute the core of Polish literature was to define the author as an imagination phenomenon that seems to fill a research gap visible in Polish Schulz studies.

Key words: Bruno Schulz; Gilbert Durand; anthropological constructs of imagination, myth, myth criticism 